\title{
Anxiety Disorders - Where Do We Stand Now? Current Medicamentous Treatment Knowledge and Future Perspectives
}

\author{
Nikola M. Stojanović ${ }^{1}$, Gordana Nikolić1,2, Milica Todorovska ${ }^{1,3}$, Pavle J. Randjelović4, \\ Nenad I. Stojiljković ${ }^{4}$, Niko S. Radulović ${ }^{3}$ \\ ${ }^{1}$ University of Niš, Faculty of Medicine, Niš, Serbia \\ ${ }^{2}$ Clinic for Mental Health, Clinical Center Niš, Niš, Serbia \\ ${ }^{3}$ University of Niš, Faculty of Sciences and Mathematics, Department of Chemistry, Niš, Serbia \\ ${ }^{4}$ University of Niš, Faculty of Medicine, Department of Physiology, Niš, Serbia
}

\section{SUMMARY}

The frequency of anxiety disorders has been significantly increasing during the last few decades, especially within the younger population. This review article inclines to explain the differences between fear and anxiety, types of disorders that might mimic anxiety or induce it, and the involvement of different neural circuits in the processing of anxiety information. A significant portion of the paper is dedicated to the current pharmacological treatment of these disorders which represents a basis for the treatment of anxiety. Also, we addressed a potential application of herbal remedies for the treatment of different anxiety spectrum disorders.

Key words: anxiety, fear, brain structures, pharmacotherapy, herbal medicines

Corresponding author:

Nikola M. Stojanović

E-mail: nikola.st90@yahoo.com 


\section{Anxiety and fear}

In an everyday conversation, both words "anxiety" and "fear" is very often used, although the ones using them most frequently are not aware of the difference between the two terms. When trying to explain the differences, one needs to go back to the end of the $19^{\text {th }}$ century when the term "emotions" was defined (1). Over the last 100 years, the definition of emotions was changed and adapted according to a new pool of knowledge coming from the fields of physiology, psychiatry, psychology, etc. (1). These theories added/subtracted something from the previous ones in order to make the new one up-to-date. The majority of the researchers agree on the existence of primitive emotions that serve as "building blocks" for more complex emotions (1). Today, fear is considered to be one of the basic (primitive) emotions that can be seen in a vast number of living beings (1).

The difference between these two terms seems to be vague. One can argue that fear arises from specific external stimuli, while anxiety could arise from either internal conflict or unknown threat (2). Also, anxiety often has some specific external object/situation that when encountered leads to an excessive fear response (3). Human beings experience fear/anxiety at an early age (during the oral stage according to the psychoanalytical theory) and this sensation is argued to occur for the first time during childbirth (birth trauma according to Freud) or later during adaptation to the environment /surroundings (according to Abraham and Klein) (4).

Anxiety is known to be an adaptive reaction in conscious living beings, i.e. humans. Besides the emotional component, a great portion of anxiety depends on the cognitive processing of "dangerous" stimuli. This cognitive component is related to previous anxiety expe- riences, e.g. cognitive concerns about oneself, potential consequences, and anticipation of future negative consequences. In general, all stimuli are potentially neutral and the interpretation of the obtained information dependant on our (conscious) mind. The cognitive and emotional components could function independently and numerous studies provided evidence for such claims (5). For example, five days prior to an important exam, students' worry levels were significantly elevated, while emotionality was unaffected. Thus, as stated in the work of Morris and co-workers (5) "...worry is aroused and maintained by situational factors that influence one's cognitive evaluations.". Also, it is evident that there are significant differences between anxiety disorders seen in humans and fear conditioning models in animals that only mimic the real disorders (3). These differences (absence of unconditioned stimuli, avoidance, and cognitive component) probably arise from the difference in anatomical structures of the brain, especially the areas of the prefrontal cortex that are unique to humans (3).

\section{Physiological and pathological anxiety}

The difference between physiological and pathological anxiety is much clearer than the difference between anxiety and fear. The differences between the two are given in Table 1. Still, sometimes the difference can be vague since there are no distinct signs and symptoms associated with anxiety and the obtained facts are based on patients' subjective interpretation and behavior. The intensity of anxiety symptoms is not following the pattern 'all or nothing', which is in agreement with the different intensity of arousal provoked by different emotions (6).

Table 1. Differences between physiological and pathological anxiety

\begin{tabular}{lll}
\hline \hline Anxiety & Physiological & Pathological \\
\hline Function & Meaningful & Useless \\
Duration & Short & Short and long \\
Intensity & Strong & Weak/medium/strong \\
Cause & Objective threat & Frequently irrational \\
Attention & Shortly affected & Prolonged decrease \\
Everyday functioning* & Unaffected & Significantly altered \\
Somatic manifestation & Rare to none & Frequent \\
\hline \hline
\end{tabular}

*Social, interpersonal relations at work, within family 
The occurrence of anxiety disorders in humans is, according to Barlow, the consequence of different vulnerabilities (triple vulnerability theory), i.e. generalized (i) biological (genetic origin; anxious temperament; low threshold for fight-or-flight reaction) and (ii) psychological (early-life experience), and (iii) specific psychological (specific events/circumstances) vulnerabilities (7). He also claims that without anxiety humans would accomplish only so little in their lives and that such a state could be deadly for the species as a nuclear war (8).

\section{The somatic manifestation of anxiety}

Somatic symptoms might be part of the clinical expression of anxiety disorders, due to the expression of one's emotions through physical complaints and distress. The term somatization itself is generally accepted and frequently used, however, it must be differentiated from the term somatization disorder, which is a distinct clinical psychiatric disorder (9). The somatization affects different organ systems but most frequently the patients' complaints are related to chest discomfort, heart palpitations, shortness of breath, stomach discomfort, etc. The role of biogenic amines (noradrenaline, serotonin, and dopamine) in the pathogenesis of anxiety can be attributed to the pathogenesis of certain somatic symptoms that accompany anxiety. For example, the regulation of heart rate and respiratory frequency following sympathetic nervous system activation is connected to nucleus paragigantocellularis (nPGi) activity, which in turn is affecting the tone of locus coeruleus (LC) (10). Additionally, changes in the postganglionic sympathetic and parasympathetic neuron function, due to emotional instability (e.g. anxiety disorders), is followed by a series of motor, secretory and immunological disturbances in the gastrointestinal tract (11). Also, the changes in primary afferent neurons, especially from the vagal nerve which arrive through caudal medulla to nucleus tractus solitarii, affect the gut-brain communication (12).

One can look the other way around, in some cases, somatic disorders (medical illness) can be the trigger of anxiety. A large number of endocrine (adrenal cortex diseases, diabetes, pheochromocytoma, etc.), cardiovascular (mitral valve prolapse), circulatory (hypovolemia, cerebral insufficiency, etc.), respiratory (asthma, pneumonia), neurologic (brain tumors, cerebral syphilis, migraine, polyneuritis, etc.) and gastrointestinal (colitis, peptic ulcer) disorders are known to cause anxiety (13). This type of anxiety can be differed from real anxiety disorders based on symptoms that could be obtained from extensive anamnesis and thorough examination (13).

\section{Anxiety disorder classification and epidemiology}

According to the $10^{\text {th }}$ International classification of diseases (ICD-10), there is a whole group of anxiety, stress-related and somatoform disorders divided into four large subgroups: phobic anxious disorders, other types of anxiety disorders, obsessive-compulsive disorders and reaction to severe stress and accommodation disorders. A recent review article suggested that a 12month prevalence of anxiety disorders is around $10 \%$, with the female gender being two times more affected than the male (14). With old age, the incidence of anxiety disorders seems to be decreasing (15), and such claims were confirmed in a Serbian population (south Serbia) as well (16). The occurrence rate of anxiety disorders seems to be relatively low in the Central/Eastern European region (3.2\%) compared to other regions of the world. Also, the same review reported an increase in anxiety disorders in young adults (14). Although animal models are able to mimic some kind of anxiety (anxiety-like) behavior, it is almost impossible to differentiate between different clinically recognized forms of anxiety disorders (17).

\section{Clinically recognized forms of anxiety disorders}

Both ICD-10 and Diagnostic and Statistical Manual of Mental Disorders (5th Edition) recognize six distinctive classes of disorders: generalized anxiety disorder (GAD), panic disorder (PD), specific phobia (SP), social anxiety disorder (SAD), agoraphobia (AP) and posttraumatic stress disorder (PTSD). Since none of the disorders are the focus of this review article, we will only briefly explain their major characteristics.

\section{Generalized anxiety disorder (GAD)}

This rather "new" disorder was introduced in the 1980s and the main difference from panic disorders is lying in its chronicity, although the difference between them is still debatable and unaccepted fully (4). Etiology is, as in all anxiety disorders, multifactorial, and the impact of different factors is not equally important. The main clinical difference between GAD and other anxiety 
disorders is in the number of anxiety (fear) inducing sources, as well as their ambiguity (18). Motor tension and autonomic hyperactivity (e.g. muscle tension, restlessness, and sleep disturbances) are frequently associateed with GAD (13).

\section{Panic disorder (PD)}

A panic attack is the most intensive anxiety attack with mainly stereotypical physical, cognitive and behavioral components that can further progress to some much more complex disorders such as depression, alcoholism, persistent anxiety, etc. (13). The patients suffering from PD have a strong physical component, sympathetic arousal, with thoughts related to a sense of terror or fear of dying or going crazy. The onset of PD in early adulthood is connected to an anxiety-related situation in childhood; also, one cannot oversee a strong genetic basis of PD previously proven in twin studies (13).

\section{Social anxiety disorder (SAD; Social phobia)}

This disorder is diagnosed in persons that have the perception that they are going to be an object of public scrutiny and/or are afraid that their behavior in public will be humiliating (13). Thus, SAD can be manifested as a person's inability to talk in front of people, eating in the presence of others, etc. Also, SAD is frequently associated with depression and alcoholism.

\section{Agoraphobia}

Exposure to specific situations in which, besides excessive fear, a person has a hard time escaping, is considered to be the main characteristic of AP. The person suffering from AP is afraid of the specific negative outcome of the situation that the person is in and he/she is actively avoiding such situations. The intensity and duration of symptoms significantly affect all areas of a patient's functioning and could lead to despair and depression (19).

\section{Posttraumatic stress disorder (PTSD)}

Although this entity existed as such for many years (one may say centuries), its precise definition was introduced during the $20^{\text {th }}$ century. The PTSD is occurring due to the inability of someone to integrate traumatic experiences in their memory, which leads to intrusions (flashbacks, somatic sensations, nightmares, etc.), avoidance/paralysis and inability to modulate arousal (6).

\section{Brain structures (neural circuits) involved in fear and anxiety}

The neuro-anatomical "basis" of fear and physiological/pathological anxiety might be considered identical and this basis can be tracked all the way back to more primitive organisms such as rodents (mice and rats) (1, 18, 20). These "basic" structures include deep brain regions such as the thalamus, limbic system (amygdala, hippocampus, entorhinal cortex, olfactory bulb, etc.), LC, the reticular activating system (RAS), as well as their connections $(1,18)$. Not so long ago, it was considered that the limbic system is involved in both emotional and cognitive tasks (dichotomy); however, more current and advanced research completely rejected such theories (1).

The first structure that integrates and processes different inputs (relays) arriving from our senses (visual, auditory, etc.) to the primary sensory cortex is the thalamus with its nuclei (18). These inputs are called peripheral and cortical, while the thalamic nuclei are classified as either first-order (bottom-up or thalamo-cortical nuclei) and higher-order (top-down or cortico-thalamic) nuclei. Contemporary studies revealed that peripheral and cortical inputs converge (via large synapses) in the whiskers-related portion of the posterior nucleus of the thalamus, where this nucleus reports "the relative timing between sensory events and ongoing cortical activity." (21). These claims are only confirmed for the posterior thalamic nucleus, however, it is speculated that the same can be attributed to other thalamic nuclei which are involved in the control of eye movements, basilar membrane dynamics, the perception of specific features of external objects, etc. (21).

The most important part of the limbic system involved in external stimuli processing is the amygdala, which performs a rapid, automatic analysis of potentially dangerous stimuli (1). One of the first researchers who established the existence of neural circuits involved in fear processing was Ivan Pavlov during the 1920s (1). Nowadays, we understand that unconditioned and conditioned stimuli are integrated (associated) in the lateral nucleus of the amygdala (22). The inputs that amygdala (lateral amygdala to be more precise) receives are mainly direct and rapid ones arriving from the thalamus, while the ones arriving from cortical structures (sensory cortex) are longer and slower (1). The amygdala processes the stimulus by attributing an emotional experience (based on our memories) to it and sends the inputs to LC, 
hypothalamus, hippocampus and prefrontal cortex (6). In turn, the function of the basolateral amygdala is found to be sensitive to the noradrenergic neurotransmission from LC, where an increase in noradrenaline release causes conditions' aversion and increases anxiety-like behavior (20). Parts of the limbic system are connected to an even older structure of the CNS, i.e. RAS. Strong stimuli that activate RAS also activate the ascending projections to the thalamus and further to the cortex (causing cortical activation) thus preparing the organism for flightor-fight reaction. In parallel, descending projections from RAS influence the spinal cord causing postural changes in tone and induce locomotor events (23). Although the hippocampus is considered to be part of the limbic system involved in generating fear impulse, new findings suggest that its main role is in learning and fear modulation in the presence of safety and threat contexts (18).

The role of LC is presumably crucial for fear/anxiety stimuli integration since the inputs from the amygdala (which are processed) and other structures that are related to visceral stimuli are relayed by the nucleus tractus solitarius (1). The main neurotransmitter found in vesicles of LC neurons is noradrenaline which affects central nervous structures both directly modulating their function and indirectly by altering the function of some other organ system (20). Noradrenaline was found to exert its action via both types of adrenergic receptors $(\alpha$ and $\beta$ ) which are related to different cognitive functions (20).

Apart from the subcortical structures, numerous cortical areas are involved in the processing of anxiety stimuli. The occipital region, involved in visual stimuli processing, and fusiform gyrus, comprised of neurons involved in face perception, are found to be significantly more activated in patients suffering from anxiety disorders or to be more precise those with SAD (18). In humans, the role of the prefrontal cortex (PFC) is to integrate all pieces of information, arriving from the posterior associative cortex, temporal, parietal zone and transform them into mental images and terms in the process of conceptualization. Different regions of PFC such as dorsolateral, ventromedial and orbital sectors have different specific roles in perception and modulation of anxiety stimulus. The conscious recognition of dangerous, unknown threats and planned targeted reaction is performed in this structure. There is a debate how the hyper- or hypo-function of this cortex region reflects on anxiety disorders and it is considered that different functioning of this region may be associated with different symptom profiles seen in different anxiety disorders (18).

\section{Treatment of anxiety disorders}

During the last few decades, there is a significant increase in all aspects of anxiety disorders' research, with a tendency to decrease the burden that anxiety patients carry. These claims are especially related to the pursuit for new drugs for anxiety management since untreated anxiety is related to high personal and societal costs, such as recurrent primary and acute care visits, decreased work productivity and/or unemployment and impaired social relationships (24). The need for a pharmacological treatment of anxiety disorders is increased by the duration and severity of the disease, the impact of symptoms on everyday life, and the presence of coexisting symptoms (25).

Pharmacotherapy, as well as psychotherapy, is efficient in the treatment of anxiety disorders (26). The particular pharmacological treatment choice should be influenced by the characteristics of the patient (i.e. age, comorbidities, treatment contraindications), and by the evidence-based drug treatment research. The modern pharmacological treatment should succeed in achieving remission and preventing relapse across all symptom domains and a broad severity range (27). The response rates to pharmacotherapy can often be substandard in clinical practice, thus the improvement in, and the development of novel, more effective and better-tolerated treatment options are clearly needed (27).

There are many available options for the pharmacological treatment of anxiety disorders (Table 2). Current first-line treatment recommendations encompass several selective serotonin reuptake inhibitors (SSRIs), serotonin-noradrenaline reuptake inhibitors (SNRIs) and $\alpha 2 \delta$ anxiolytic drug pregabalin. Other, nowadays outdated, options include tricyclic antidepressants (TCAs), monoamine oxidase inhibitors, and a range of benzodiazepines (BZD) (27).

\section{Selective serotonin reuptake inhibitors (SSRIs) and selective serotonin-noradrenaline reuptake inhibit- ors (SNRIs)}

The SSRIs and SNRIs are recommended as the current first-line therapy due to the positive benefit/risk balance they exhibit. The onset of the anxiolytic effects of these drugs has a latency of 2 to 4 weeks (in some cases up to 6 weeks) (28). Adverse effects might be more prominent during the first weeks, including the initial agitation or an increase in anxiety symptoms. The reduction of these adverse effects is managed usually by lowering 
the starting dose of the drug. After the treatment discontinuation, mild withdrawal reactions may occur (most frequently with paroxetine). Drug tolerability may differ among patients, and an interaction with other drugs is also possible since some SSRIs and SNRIs are cytochrome P450 enzyme inhibitors and hence may interact with other medication for medical illnesses (29).

Table 2. Overview of treatment options in anxiety disorders (31)

\begin{tabular}{|c|c|c|}
\hline $\begin{array}{l}\text { Anxiety } \\
\text { disorder }\end{array}$ & First-line treatment & Second-line treatment \\
\hline GAD & $\begin{array}{c}\text { Venlafaxine XR 75-150 mg/day, } \\
\text { SSRI (e.g., Paroxetine } 20 \mathrm{mg} / \text { day, Escitalopram } 10 \mathrm{mg} / \text { day) }\end{array}$ & $\begin{array}{l}\text { Imipramine } 150 \mathrm{mg} / \text { day, } \\
\text { Buspirone } 15-630 \mathrm{mg} / \text { day }\end{array}$ \\
\hline OCD & $\begin{array}{c}\text { SSRI (e.g., Fluoxetine } 20-60 \mathrm{mg} / \mathrm{day}, \text { Fluvoxamine } \\
\text { 50-300 mg/day, Paroxetine } 20-40 \mathrm{mg} / \text { day, } \\
\text { Sertraline 50-200 mg/day }\end{array}$ & Clomipramine $150-250 \mathrm{mg} /$ day \\
\hline PD & $\begin{array}{l}\text { SSRI } \pm \text { benzodiazepine (e.g., citalopram } 20-60 \mathrm{mg} / \text { day, } \\
\text { Escitalopram 5-20 mg/day, Paroxetine } 10 \mathrm{mg} / \text { day, } \\
\text { increasing up to } \max 50 \mathrm{mg} / \text { day })\end{array}$ & $\begin{array}{l}\text { Clomipramine } 150 \mathrm{mg} / \text { day, } \\
\text { Imipramine } 150 \mathrm{mg} / \text { day, } \\
\text { Phenelzine } 30-60 \mathrm{mg} / \text { day, } \\
\text { Alprazolam 30-60 mg/day }\end{array}$ \\
\hline PTSD & $\begin{array}{l}\text { SSRI (e.g., Paroxetine 20-50 mg/day, Sertraline 50-200 } \\
\text { mg/day) }\end{array}$ & $\begin{array}{l}\text { Amitriptyline } 150-200 \mathrm{mg} / \text { day, } \\
\text { Mirtazapine } 30-45 \mathrm{mg} / \text { day, } \\
\text { Phenelzine } 30-60 \mathrm{mg} / \text { day }\end{array}$ \\
\hline SAD & $\begin{array}{l}\text { SSRI (e.g., Paroxetine 20-50 mg/day, Venlafaxine 75-150 } \\
\text { mg/day) }\end{array}$ & Phenelzine 30-60 mg/day \\
\hline SP & 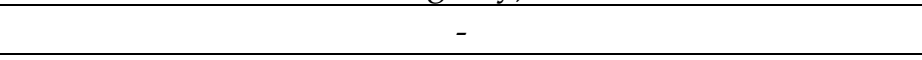 & SSRI (e.g., paroxetine $20 \mathrm{mg} /$ day) \\
\hline DCA & $\begin{array}{c}\text { SSRI } \pm \text { benzodiazepine } \\
\text { (e.g., Paroxetine 20-40 mg/day, Mirtazapine } 30-45 \mathrm{mg} / \text { day, } \\
\text { Venlafaxine } 75-150 \mathrm{mg} / \text { day }) \\
\end{array}$ & $\begin{array}{l}\text { Amitriptyline } 75-150 \mathrm{mg} / \text { day, } \\
\text { Clomipramine } 75-150 \mathrm{mg} / \text { day }\end{array}$ \\
\hline
\end{tabular}

\section{Pregabalin}

Pregabalin, a GABA derivative, acting at the $\alpha 2 \delta$ subunit of voltage-gated calcium channels, is a wellknown drug used in the treatment of anxiety disorders $(25,28)$. The clinical trials evidence shows that the onset of efficacy is prior to the one with antidepressants. The symptom improvement is comparable to the one achieved with antidepressants, making pregabalin a striking support option in antidepressant non-responders (30). Pregabalin displays sedating properties but improves sleep disorder conditions, which are common in patients with anxiety disorders. This drug is not subject to hepatic metabolism, hence does not interact with inhibitors or inducers of cytochrome P450 enzymes (28).

\section{Tricyclic antidepressants}

Imipramine and clomipramine, TCAs, are effective in some anxiety disorders as second-generation antidepressants (30). The initial dose should be low and increased slowly every three to five days until levels reach those matching the ones used in the treatment of depression (29). They are, in general, associated with a larger number of adverse reactions than SSRIs and SNRIs, such as anticholinergic effects, $\alpha 1$ adrenergic blocking effects, and antihistamine effects. Since TCAs are cardiotoxic, they should be used with caution in patients with cardiovascular disorders or those considered at risk of suicide, due to their potentially fatal toxicity after overdose (30). 


\section{Benzodiazepines}

Benzodiazepines act by facilitating the opening of ligand-gated chloride channels, thus enhancing the effects of GABA, an inhibitory neurotransmitter. Individual BZDs differ with respect to their effectiveness, halflife, and the onset of action. In general, the onset of anxiolytic effects is demonstrated shortly after the application (32). BZD-related treatment may be associated with CNS depression, impaired cognitive functions, for the most part in elderly patients, and after prolonged treatment, i.e. over 4 to 8 months, dependence may occur, while tolerance is infrequent. Current guidelines do not recommend benzodiazepines as the first-line treatment (30), but suggest that BZDs may be used in combination with SSRIs/SNRIs during the first weeks before the onset of efficacy of the antidepressants (33).

\section{Herbal medicines}

Due to the ever-increasing number of phytotherapeutic preparations possessing upright clinical evidence, the role of herbal medicines in the treatment of psychiatric disorders has become customary over the past years (34). These alternative products appear to be safer than traditional pharmacotherapy, with lower adverse effect occurrence rates (35). Moreover, a significant number of patients prefer herbal preparations for symptom relief to conventional drugs. However, one must bear in mind that only a number of preparations have sufficient evidence in the treatment of depression, but not for anxiety disorders, suggesting the need for larger, well-designed clinical trials to determine their relevance. The herbal medicines currently used in clinical practice are given in Table 3.

Table 3. Herbal medicines used in anxiety, depressive and schizophrenic disorders (34)

\begin{tabular}{|c|c|c|}
\hline Binomial plant taxon name & Common plant taxon name & Disorder/symptom \\
\hline Bacopa monnieri (L.) Wettst. & Water hyssop, Indian pennywort & GAD \\
\hline Centella asiatica (L.) Urb. & Gotu kola & Generalized anxiety and stress, GAD \\
\hline Citrus $\times$ aurantium $\mathrm{L}$. & Bitter orange & GAD \\
\hline Crocus sativus L. & Saffron, Autumn crocus & MDD, GAD \\
\hline Galphimia glauca Cav. & Galphimia, Golden thryallis & GAD \\
\hline Ginkgo biloba L. & Ginkgo & $\mathrm{GAD}, \mathrm{SD}, \mathrm{BD}$ \\
\hline Matricaria chamomilla $\mathrm{L}$. & Chamomile & GAD \\
\hline Melissa officinalis L. & Lemon balm, Common balm & GAD, stress, mood disturbance, $\mathrm{SOM}$ \\
\hline Nepeta spp. & Catmint, Catnip & GAD \\
\hline Panax ginseng C.A.Mey. & Ginseng, Korean ginseng & MDD, GAD \\
\hline Passiflora edulis Sims & Passion fruit & GAD, SOM \\
\hline Piper methysticum G.Forst. & Kava & GAD, SP, AnxD \\
\hline Rhodiola rosea $\mathrm{L}$. & Golden root, Rose root & MDD, GAD \\
\hline Scutellaria lateriflora $\mathrm{L}$. & Blue skullcap & GAD \\
\hline Valeriana spp. & Valerian & GAD, AnxD, SOM \\
\hline $\begin{array}{l}\text { Withania somnifera (L.) } \\
\text { Dunal }\end{array}$ & Ashwagandha, Indian ginseng & $\mathrm{SCHZ}, \mathrm{BD}, \mathrm{GAD}$ \\
\hline
\end{tabular}

$\mathrm{GAD}=$ generalized anxiety disorder; $\mathrm{MDD}=$ major depressive disorder; $\mathrm{SD}=$ seasonal affective disorder; $\mathrm{BD}=$ bipolar disorder; $\mathrm{SOM}=$ somatoform disorder; $\mathrm{SP}=\mathrm{s}$ ocial phobia; $\mathrm{AnxD}=$ anxious depression; $\mathrm{SCHZ}=$ schizophrenia. 


\section{CONCLUSION}

Although there is a significant number of anti-anxiety drugs used in everyday, clinical practice, there is a constant pursuit for new and more effective drugs that will help us cope with these disorders. Natural based herbal products seem to represent a potential source for new drug candidates, however, due to a limited amount of research performed, it is vital for us to conduct rigorous experiments to evaluate their utility, drug interactions and possible side effects related to their consum- ption. Also, the applicability of SSRIs in the treatment of anxiety might need to be reassessed since there are numerous side effects occurring after prolonged usage.

\section{Acknowledgment}

This publication is a part of Nikola M. Stojanovićs PhD thesis, under the supervision of Pavle J. Randjelović. This work was supported by the Ministry of Education, Science and Technological Development of the Republic of Serbia (Project No. 172061). 


\section{References}

1. Steimer T. The biology of fear- and anxiety-related behaviors. Dialogues Clin Neurosci 2002; 4: 231-49.

2. Craig KJ, Brown KJ, Baum A. Environmental factors in the etiology of anxiety. In: Bloom FE, Kupfer DJ, eds. Psychopharmacology: the Fourth Generation of Progress. Raven Press, New York, 1995: 1325-39.

3. Shin LM, Liberzon I. The neurocircuitry of fear, stress, and anxiety disorders. Neuropsychopharmacology 201; 35: 169-91.

https://doi.org/10.1038/npp.2009.83

4. Starčević V. Bez straha, o strahu, panici i fobiji. Mladost Biro, Beograd, 2005. (The book is written in Serbian)

5. Morris LW, Davis MA, Hutchings $\mathrm{CH}$. Cognitive and emotional components of anxiety: literature review and a revised worry-emotionality scale. J Educ Psychol 1981; 73: 541-55.

https://doi.org/10.1037/0022-0663.73.4.541

6. Nešić M. Pshichoneuroendocrino-immunology of stress, Faculty of Medicine, Niš, Serbia 2005. (The book is written in Serbian)

7. Barlow DH. Unraveling the mysteries of anxiety and its disorders from the perspective of emotion theory. Am Psychol 2000; 55: 1247-63. https://doi.org/10.1037/0003-066X.55.11.1247

8. Barlow DH. Anxiety and its disorders: The nature and treatment of anxiety and panic. The Guilford Press, New York, 1988.

9. Gelenberg AJ. Psychiatric and somatic markers of anxiety: identification and pharmacologic treatment. Prim Care Companion J Clin Psychiatry 2000; 2: 4954.

\section{https://doi.org/10.4088/PCC.v02n0204}

10. Blaustein JD. Handbook of Neurochemistry and Molecular Neurobiology: Behavioral Neurochemistry, Neuroendocrinology and Molecular Neurobiology. Springer, 2006.
11. Mayer EA. Gut feelings: the emerging biology of gut-brain communication. Nat Rev Neurosci 2011; 12: 10.1038/nrn3071. https://doi.org/10.1038/nrn3071

12. Emond M, Schwartz GJ, Moran TH. Meal-related stimuli differentially induce c-Fos activation in the nucleus of the solitary tract. American Journal of Physiology-Regulatory, Integrative and Comparative Physiology 2001; 280: R1315-21.

https://doi.org/10.1152/ajpregu.2001.280.5.R1315

13. Stern T, Fricchione G, Rosenbaum J. Massachusetts General Hospital Handbook of General Hospital Psychiatry. $6^{\text {th }}$ Edition. Saunders Elsevier, Philadelphia, 2010: 133-52.

14. Remes $\mathrm{O}$, Brayne $\mathrm{C}$, van der Linde $\mathrm{R}$, Lafortune L. A systematic review of reviews on the prevalence of anxiety disorders in adult populations. Brain Behav 2016; 6:e00497.

https://doi.org/10.1002/brb3.497

15. Bandelow, B. Epidemiology of anxiety disorders in the 21st century. Dialogues Clin Neurosci 2015; 17: 327-35.

16. Stojanović NM, Samardžić Lj, Randjelović PJ, Radulović NS. Prevalence of self-medication practice with herbal products among non-psychotic psychiatric patients from southeastern Serbia: A cross-sectional study. Saudi Pharm J 2017; 25: 884-90. https://doi.org/10.1016/j.jsps.2017.02.002

17. Bourin M. Animal models for screening anxiolyticlike drugs: a perspective. Dialogues Clin Neurosci 2015; 17: 295-303.

18. Duval ER, Javanbakht A, Liberzon I. Neural circuits in anxiety and stress disorders: a focused review. Ther Clin Risk Manag 2015; 11: 115-26. https://doi.org/10.2147/TCRM.S48528

19. Bystritsky A, Khalsa SS, Cameron ME, Schiffman J. Current diagnosis and treatment of anxiety disorders. P T 2013;38: 30-57. 
20. McCall JG, Siuda ER, Bhatti DL, et al. Locus coeruleus to basolateral amygdala noradrenergic projections promote anxiety-like behavior. Elife 2017; 6: e18247. https://doi.org/10.7554/eLife.18247

21. Ahissar E, Oram T. Thalamic relay or corticothalamic processing? Old question, new answers. Cereb Cortex 2015; 25: 845-8.

https://doi.org/10.1093/cercor/bht296

22. Lee $S$, Shin HS. The role of mediodorsal thalamic nucleus in fear extinction. JAST 2016; 7: 13. https://doi.org/10.1186/s40543-016-0093-6

23. Garcia-Rill E, Kezunovic N, Hyde J, et al. Coherence and frequency in the reticular activating system (RAS). Sleep Med Rev 2013; 17: 227-38.

https://doi.org/10.1016/j.smrv.2012.06.002

24. Simpson HB, Neria Y, Lewis-Fernandez R, and Schneier F. Anxiety disorders - theory, research and clinical perspectives. $1^{\text {st }}$ ed Cambridge University Press, Cambridge. 2010. https://doi.org/10.1017/CBO9780511777578

25. Baldwin DS, Brandish E. In: The Wiley Handbook of Anxiety Disorders, First Edition. Eds. Emmelkamp P, Ehring T. John Wiley \& Sons, Ltd. 2014.

26. Thibaut F. Anxiety disorders: a review of current literature. Dialogues Clin Neuroscience 2017: 19; 878.

27. Baldwin DS. Room for improvement in the pharmacological treatment of anxiety disorders. Curr Pharm Des 2008; 14: 3482-91. https://doi.org/10.2174/138161208786848810
28. Bandelow B, Michaelis S, Wedekind D. Treatment of anxiety disorders. Dialogues Clin Neurosci 2017; 19: 93-106.

29. Muscatello MR, Spina E, Bandelow B, Baldwin DS. Hum Psychopharmacol 2012; 27: 239-53.

https://doi.org/10.1002/hup.2217

30. Hanson C, Modiba W. Overview and management of anxiety disorders. S Afr Pharm J 2017; 84: 43-50.

31. Nutt DJ. Overview of diagnosis and drug treatments of anxiety disorders. CNS Spectrums 2005; 10: 49-56. https://doi.org/10.1017/S1092852900009901

32. Katzung B, Masters SB, Trevor AJ. Basic and Clinical Pharmacology. 12 ${ }^{\text {th }}$ Ed. McGraw-Hill Lange, 2012.

33. Goddard AW, Brouette T, Almai A, et al. Early coadministration of clonazepam with sertraline for panic disorder. Arch Gen Psychiatry 2001; 58: 681-6. https://doi.org/10.1001/archpsyc.58.7.681

34. Sarris J. Herbal medicines in the treatment of psychiatric disorders: 10-year updated review. Phytother Res 2018; 32: 1-16.

https://doi.org/10.1002/ptr.6055

35. Yeung KS, Hernandez M, Mao JJ, et al. Herbal medicine for depression and anxiety: A systematic review with assessment of potential psycho-oncologic relevance. Phytother Res 2018; 32: 1-27. https://doi.org/10.1002/ptr.6033 


\title{
Anksiozni poremećaji - trenutno stanje stvari? Preporučena medikamentozna terapija i perspektive
}

\author{
Nikola M. Stojanović ${ }^{1}$, Gordana Nikolić1,2, Milica Todorovska1,3, Pavle J. Ranđelović4, \\ Nenad I. Stojiljković4 ${ }^{\text {, Niko S. Radulović }}{ }^{3}$ \\ ${ }^{1}$ Univerzitet u Nišu, Medicinski fakultet, Niš, Srbija \\ ${ }^{2}$ Klinika za zaštitu mentalnog zdravlja, Klinički centar Niš, Niš, Srbija \\ ${ }^{3}$ Univerzitet u Nišu, Prirodno-matematički fakultet, Departman za hemiju, Niš, Srbija \\ ${ }^{4}$ Univerzitet u Nišu, Medicinski fakultet, Institut za fiziologiju, Niš, Srbija
}

\section{SAŽETAK}

Učestalost anksioznih poremećaja je značajno povećana poslednjih decenija, a posebno među mlađim generacijama. Ovaj pregledni članak je usmeren da objasni razliku između straha i anksioznosti, a baviće se i poremećajima koji mogu da imitiraju anksioznost ili da dovedu do nje, kao i neurofizioloških mehanizmima koji su uključeni u procesuiranje anksioznosti. Značajan deo ovog članka je posvećen trenutnim preporukama za medikamentoznu terapiju koja predstavlja osnovu lečenja anksioznih poremećaja. Takođe, posvetiće se pažnja i mogućoj primeni prirodnih biljnih lekova u terapiji različitih anksioznih poremećaja.

Ključne reči: anksioznost, strah, moždane stukture, farmakoterapija, prirodni biljni lekovi 